\title{
ФРАНЦУЗЬКІ КУЛЬТУРАЛЬНІ СТУДІї: ОСОБЛИВОСТІ ТА ТЕНДЕНЦІЇ
}

\section{- Носенок Богдана Едуардівна}

Аспірантка, ORCID: 0000-0002-3034-9217, e-mail: danynosenock@gmail.com, Київський національний університет імені Тараса Шевченка, вул. Володимирська, 60, Київ, Україна, 01033

\section{- Для цитування:}

Носенок, Б.Е. (2021). Французькі культуральні студії: особливості та тенденції. Питання культурології, (38), 156-165. doi: https://doi.org/10.31866/2410-1311.38.2021.245846.

\section{Анотація}

Метою статті $є$ виявлення особливостей французьких культуральних студій, а також розкриття соціального характеру французької культурології. 3 огляду на логіку цієї статті, важливе завдання - продемонструвати розвиток французьких культуральних досліджень, окреслити особливості розвитку культурології у фрранцузькому соціокультурному просторі. Методологія статті пов'язана з опрацюванням джерел, присвячених історії становлення культурології у Франції та її місця у системі наук цієї країни. У ході написання дослідницької роботи було використано міждисциплінарний підхід, настанови теорії асамбляжів. Наукова новизна статті полягає у визначенні особливостей розвитку досліджень культури у Франції. Зокрема, йдеться про пошуки місця культурології та культурологічних досліджень. Пропонована праця торкається проблемного питання про специфіку та значення Études culturelles у системі наук у Франції. Висновки. Французькі культуральні дослідження Études culturelles - зосереджуються навколо трьох ключових полів: мистецтво, письмо, мова. Французькі науковці-культурологи впевнені: лінгвістичне середовище не може існувати окремо від соціуму. Тому французькі дослідження у сфері культурології балансують між двома напрямами: humanities та social science. Було, зокрема, виявлено, що для французької культурології характерні такі моменти: розуміння культури як видимої території, на якій триває боротьба щодо захисту певної ідеї Франції; наголос на понятті «нація»; зв'язок розвитку культури та реформи освіти; створення державою універсальної системи національної освіти; увага до розвитку мови та літератури. У Франції культуральні дослідження залишаються суперечливими, вони є чимось погано зрозумілим, оскільки французькі мислителі $€$ класикою для цих міждисциплінарних гуманітарних наук. На перший план часто виходить ідея опору та «заперечення культури». Проте $є$ тема, яка об'єднує фрранцузьких культурологів: критика релятивізму, яку приписують культурології в ім'я захисту школи.

Ключові слова: культурологія; гуманітаристика; міждисциплінарність; соціальне знання; фрранцузькі культуральні дослідження 


\section{- Вступ}

Культурологія завжди враховує міждисциплінарний досвід та базується на доробку філософрії, соціології, психології, антропології, етнографії, мистецтвознавства, лінгвістики тощо (Шегавцова, 2020). Дослідження у полі культури у різних державах мають, відповідно, різні назви. При адаптації тих чи інших досліджень до вітчизняного поля гуманітаристики виникають закономірні труднощі. Так, обсяг поняття «культурологія» не збігається з обсягом поняття Cultural Studies або ж les Études culturelles. Вітчизняна культурологія стосується набагато більш широкого кола питань та проблем, ніж вищезазначені відгалуження західноєвропейської гуманітаристики. Так, якщо для вітчизняної науки характерним $€$ розмежування поля наук про культуру та наук про суспільство, то у французькій гуманітаристиці наука про культуру входить до поля соціального знання.

Культурологічна наука в цілому та культурологія у Франції цікавили багатьох дослідників, як-от: С. Козлова (2020) («Імплантація. Нариси генеалогії історико-фрілологічного знання у Франції»), Ф. Барклей (Barclay, 2021) («Постколоніальні сфери пам'яті: місця та символи в сучасній Франції»), І. Женгра (Gingras, 1991) («Інституціоналізація досліджень в університетах та їх наслідки»), К. Женен (Genin, 2006) («Мотив радикалізму. Про деякі нові тенденції в соціології науки і технологій», «Культурологія: опір Франції?», «Місце університетів у системі виробництва знань»), Ф. Олів'є-Утар (Olivier-Utard, 2003) («Динаміка подвійного спадкування. Університетсько-ділові відносини у Страсбурзі»), Т. Шінн (Schinn, 2002) («Нове виробництво знань і потрійна спіраль. Тенденції в науці, готовій до мислення»), А. Текрей (Thackray, 1980) («Історія науки. Посібник із культури науки, техніки та медицини»). Природу соціального та культурального знання, зі свого боку, вивчали М. Вебер (1990) («“Об'єктивність" соціально-наукового і соціально-політичного знання»), І. Лісович (Лисович 2015) («Скальпель розуму і крила уяви. Наукові дискурси в англійській культурі раннього Нового часу»), Р. Мертон $(1993,2007)$ («Ефект Матвія в науці, II. Накопичення вигод і символіка інтелектуальної власності», «Наука і громадський порядок»).

\section{- Мета статті}

Мета статті - виявлення особливостей фрранцузьких культуральних студій, а також розкриття соціального характеру французької культурології. Завданнями статті є: розкриття сутності та історії становлення Études culturelles - як частини культуральних досліджень у Франції. У ході написання дослідницької роботи було використано міждисциплінарний підхід, настанови теорії асамбляжів, а також наступні методи досліджень: функціональний, системний, семіотичний, аналіз текстів. Вагомими для цієї роботи є принцип цілісності, аналіз та синтез, а також сходження від абстрактного до конкретного й узагальнення. Наукова новизна статті полягає у визначенні особливостей розвитку досліджень культури у Франції. Зокрема, йдеться про пошуки місця культурології та культурологічних досліджень. Пропонована праця торкається проблемного питання про специфіку та значення Études culturelles у системі наук у Франції. 


\section{- Виклад матеріалу дослідження}

Французькі культуральні дослідження - Études culturelles - торкаються вивчення трьох ключових полів: мистецтво, письмо, мова. Лінгвістичне середовище, за логікою французьких науковців, не може існувати окремо від соціуму. Тому фрранцузькі дослідження у сфері культурології балансують між двома напрямами: humanities та social science. Як зазначає французький науковець Крістоф Женен (Genin, 2006), культурологія у Франції наповнена суперечностями. 3 одного боку, фрранцузи підозріло зустрічають англо-американські культурологічні дослідження, з іншого ж боку, вони здебільшого віддають належне французьким інтелектуалам.

Ми припускаємо, що цей фрранцузький опір не обумовлений культурною винятковістю фрранцузької культури або ж шовіністичними тенденціями культурних досліджень загалом. Швидше він пов'язаний із концепцією республіканської школи, універсалізм якої навряд чи сумісний із когнітивним релятивізмом. Слід звернутися до двох постатей - П'єра Бурдьє та Жака Дерріди, чиї позиції щодо реформ виявилися джерелами суперечностей. Тоді, на нашу думку, можна буде подолати помилкову дискусію між універсалізмом та релятивізмом.

Але спершу зазначимо внесок ще однієї персони у конституювання специфіки фрранцузьких культуральних досліджень. Взагалі ж, місце Études culturelles у французькій системі наук пов'язане з реформою вищої освіти, яка відбулась наприкінці XIX століття у Франції. У цьому контексті варто згадати постать Вiктора Дюруї (1811-1894) - фрранцузького історика та державного діяча (Женгра, 2004).

Для того, щоб зрозуміти логіку розвитку культуральних досліджень у Франції, треба звернутися до географрічного розповсюдження сучасної науки. Як пише I. Женгра (Gingras 1991), інститути, характерні для сучасної науки, виникають у Європі. Згодом їх переймають та відтворюють у більшості інших країн. Хронологія подібного запозичення визначається особливостями соціальноекономічного розвитку країни. При цьому слово «запозичення» вже передбачає наявність певної ідентичності, котра, власне, і дає змогу говорити про наявність деяких своїх, «рідних» елементів у культурі та запозичених, «чужих».

У рамках цього дослідження ми дотримуємося позиції, яка стверджує, що культура та ідентичність нерозривно пов'язані між собою, оскільки культура, безперечно, є одним зі способів побудови та вираження ідентичності - національної, етнічної, особистої. Так, можна наголосити на таких позиціях, характерних для фрранцузької культурології:

1. Культура - це видима територія, на якій триває боротьба, що визначає та захищає певну ідею Франції: у цьому контексті автор звертається до обговорення деяких шляхів, якими французька держава прагнула визначити власну ідентичність, і затвердити це визначення французькою мовою; тут важливо також виявити деякі способи, якими ми - як особистості - використовуємо культуру для визначення себе, а також окреслити деякі основні позиції французької культурології (Olivier-Utard, 2003).

2. Автори приділяють значну увагу визначенню поняття «нація»: одним із найважливіших періодів у французькій історії, принаймні з огляду спроби дер- 
жави визначити свою ідентичність через свою культуру, був період Третьої республіки (1870-1940) (Barclay, 2021). Ці роки були вирішальними для Франції: відхід домінування сільської місцевості на другий план, розбудова великих міст, сприяння вдосконаленню транспортної інфраструктури тощо - все це призвело до того, що багато французів (особливо чоловіків) переїжджали із села в місто та передмістя через індустріалізацію, а зміцнення вже більш потужного промислового робітничого класу відбувалося доволі швидко. Культурно цей період був також значущим: було запроваджено виборче право для чоловіків (тобто чоловіки отримали голос), і як початкова школа, так і військова служба (знову ж таки - для чоловіків) стали обов'язковими (Sclove, 2000).

3. Рефрорма освіти була особливо важливою, оскільки багато хто вважав, що освітня система повинна стати життєво необхідним каналом для поширення культури, проте дехто може назвати це нав'язуванням унітарної чи єдиної ідеї фрранцузької нації. Школа могла б стати передовим форпостом нації. Інститут початкової школи та інститут виховання дітей стали важливим фактором передачі певної схваленої версії історії Франції, географії та, звичайно, культури (Godin \& Gingras, 2000).

4. У Третій республіці основним засобом формування спільної республіканської культури було створення державою універсальної системи національної освіти, основною метою якої було перетворення кожної дитини у кожному куточку Франції на повноцінного і гідного громадянина нової республіканської нації (Genin, 2006).

5. Однією з найважливіших частин будь-якої культури є, звичайно, мова i, меншою мірою, література. Саме під час Третьої республіки були зроблені спроби описати і визначити французьку мову: так, у 1905 році вийшов перший том «Історії фрранцузької мови» Фердинанда Бруно, а ґрунтовна праця, присвячена фрранцузькій літературі - «Історія фрранцузької літератури» Гюстава Лансона, опублікувана у 1895 році. Було докладено спільних зусиль, щоб нав'язати французькому населенню, яке звикло до мовного різноманіття, стандартну фрранцузьку мову. Діалекти та акценти, а також відчуття регіональної ідентичності (наприклад, бретонська, окситанська мови тощо), що їх супроводжували, активно зникали зі шкільної освіти і сприймалися як загроза загальній національній ідентичності Франції (Gingras, 1991).

Хоча Третя республіка прагнула створити єдину націю, котра б розмовляла єдиною мовою та поділяла спільну культуру, для кожного, хто дивиться на Францію сьогодні, цілком зрозуміло, що насправді існує безліч мов і культур, що перебувають в обігу. У 1960-х та 1970-х роках соціологічні праці П. Бурдьє (особливо «Відмінність» 1979 року) постали як особливо важливі: вони описували Францію, що складається з незліченних культур і субкультур. Він розглядав Францію як країну, яка була не стільки об'єднаною, скільки розділеною своєю культурою.

П. Бурдьє висловлює досить негативну позицію щодо культури домінуючих груп у фрранцузькому суспільстві, розглядаючи, наприклад, культуру робочого класу як неминуче підпорядковану високій культурі середніх класів, тоді як фрранцузький філософ, культуролог, історик Мішель де Серто (Michel Jean 
Emmanuel de La Barge de Certeau, 1925-1986) притримується більш позитивної думки. Так, М. де Серто цікавиться, як звичайні люди використовують культуру та певні культурні практики, щоб визначити себе та протистояти асиміляції домінуючої культури. Зокрема, робота «Винахід повсякдення», вперше опублікована у двох томах у 1980 році, являє собою найбільш детальну спробу пояснити способи, якими звичайні люди ведуть переговори, спілкуються та використовують продукти, простори й у цілому проводять повсякденне життя (Козлов, 2020).

Культурні тексти та практики - це не просто «відображення» суспільства, в якому вони створюються. Замість того, щоб просто реферувати суспільні «дебати», культурні тексти та практики насправді допомагають їх формувати. Тому взаємозв'язок між текстом або практикою та історичним і соціальним контекстом $€$ проблематичним. У фрранцузьких культуральних дослідженнях автоматично вважається, що культура $є$ по суті політичною. Західне суспільство розділене нерівномірно за класовою, расовою та гендерною ознаками. Культура це місце, де створено ці підрозділи і де вони можуть бути оскаржені, це поле боротьби за значення, в якому домінуючі групи намагаються нав'язати значення підлеглим групам, і де підлеглі групи можуть протистояти цьому нав'язаному значенню. Тож, культуральні дослідження сьогодні у Франції привілеюють політичне і применшують естетичне.

Сучасний фрранцузький дослідник Крістоф Женен (Christophe Genin, нар. 1958) недарма називає Études culturelles «фрранцузьким парадоксом». На його думку, сьогодні фрранцузькі культуральні дослідження відчувають на собі істотний вплив англо-американського середовища (аналогічний висновок ми зробили і у другому розділі цієї роботи). Втім, більшість французьких дослідників негативно ставляться до таких тенденцій. Іронія історії полягає в тому, що американські культурологи надихали деякі - достатньо суттєві та вагомі сьогодні - фрранцузькі теорії: наприклад, це стосується позицій Луї Альтюссера, Ролана Барта, Жана Бодрійяра, Гі Дебора, Жиля Делеза, Жака Дерріди, Мішеля Фуко, Жака Лакана, Франсуа Ліотара, Мішеля де Серто, не кажучи вже про Жоржа Батая, Моріса Бланшо, Рене Жирара та ін. Ба більше: ці «легіонери» національної думки «стрибнули на парашуті на ворожу територію» - хто в Берклі, хто в Стенфорд, хто в Єль. Так, досвід вивчення та безпосереднього контакту з англо-американською культурою мають, зокрема, Сімона де Бовуар, Елен Сіксо, Люс Іріґарей, Сара Коуфман, Юлія Крістева та інші. Іронія історії полягає в тому, що основоположник англійського культуризму Едвард Тайлор захоплювався Огюстом Контом. Проте К. Женен (Genin, 2006) зазначає: «Але якби я був австрійцем (Віденський університет), чи камерунцем (Університет Яунде), чи канадцем (Університет Ватерлоо), чи датчанином (Університет Оденce), чи фріном (Університет Туруна), чи японцем (Університет Кобе), або турком (Університет Докуз Ейлюль), маніфест для культурологічних досліджень здався б мені ар'єргардним боєм».

Вважати, що течія думок обмежена національним генієм, - означає не розуміти процеси інтелектуального обміну та навчання. Це також нерозуміння, засноване на націоналістичних припущеннях, - нерозуміння сутності Cultural Studies, Kulturstudien, estudios culturales, studi culturali або культурології - на- 
віть якщо між ними існують розбіжності в інтересах або пріоритетах. А втім, у Франції культуральні дослідження залишаються суперечливими, вони $є$ чимось погано зрозумілим, оскільки французькі мислителі - класика для цих міждисциплінарних гуманітарних наук. У чому причина такого заперечення культури? Причин багато, тому охопити їх усі в одному розділі важко. Проте, слідом за К. Жененом, ми також будемо йти за темою, котра $є$ типовою для французьких культуральних досліджень: критика релятивізму, яку приписують культурології в ім'я захисту школи. Тобто це своєрідне дослідження культурного опору.

\section{- Висновки}

Французькі культуральні дослідження, зокрема, зосереджуються навколо наступних ключових питань: технологічний прогрес (масове виробництво та розповсюдження друкованих та аудіовізуальних матеріалів); міжнародна перебудова (із закінченням імперії зникло поняття культурного універсалізму, тобто ідеї, що французька культура має загальнолюдську цінність та представляє весь людський досвід), яка обґрунтовувала колонізацію; поява глобалізації (фрранцузька національна культура стала замінюватися англо-американським культурним домінуванням); зміни соціально-культурних моделей (різні режими споживання культури почали з'являтися з новим заможним робітничим класом). Тобто справді, культуральні дослідження у Франції мають соціальну природу.

Культуральні дослідження наполягають на понятті культури як способу життя. Культура - це не просто те, чим ми займаємось, це те, ким ми є, тобто вона $€$ невід'ємною частиною того, як ми реалізуємо свої стосунки зі світом. Отже, культурологія спирається як на соціальні науки, так і на літературознавство чи інші гуманітарні дисципліни і відрізняється мультидисциплінарністю. Культура соціально та історично конституйована. Значення культурних текстів або практик повинно бути проаналізовано з огляду конкретного історичного моменту його виробництва та конкретного історичного моменту його споживання. Культурні тексти та практики не мають суттєвого значення.

\section{- Список використаних джерел}

Вебер, М. (1990). Избранные труды. Прогресс.

Жангра, И. (2004). Мотив радикализма. О некоторых новых тенденциях в социологии науки и технологий. Журнал социологии и социальной антропологии, 7(5), 75-98. http://bourdieu.name/files/Zhangra\%20lv.\%20Motiv\%20radikalizma\%20 $($ ZhSSA, \%202004)(ru)(T)(24s).pdf

Козлов, С. Л. (2020). Имплантация. Очерки генеалогии историко-филологического знания во Франции. Новое литературное обозрение.

Лисович, И. И. (2015). Скальпель разума и крылья воображения: Научные дискурсы в английской культуре раннего Нового времени. Издательский дом Высшей школы экономики.

Мертон, Р. (1993). Эфффект Матфея в науке, II. Накопление выгод и символика интеллектуальной собственности. THESIS, 3, 256-276.

Мертон, Р. (2007). Наука и общественный порядок. Вопросы социальной теории, 1(1), 191-207. https://iphras.ru/uplfile/root/biblio/vst/2007/merton.pdf 
Шегавцова, С. (2020). Лінгвокультурологічна компетентність майбутніх фрахівців як ключова у сучасному освітньому просторі. Вісник Луганського національного університету імені Тараса Шевченка: Педагогічні науки, 2(333), 2, 72-79.

Barclay, F. (2021). Postcolonial Realms of Memory: Sites and Symbols in Modern France. French Studies, 75(3), 420-421. https://doi.org/10.1093/fs/knab076

Genin, Ch. (2006). Les études culturelles : une résistance française? MEl, 24-25 (Études culturelles/Cultural Studies), 43-55.

Gingras, Y. (1991). L'institutionnalisation de la recherche en milieu universitaire et ses effets. Sociologie et sociétés, 23(1), 41-54.

Godin, B., \& Gingras, Y. (2000). The place of universities in the system of knowledge production. Research policy, 29(2), 273-278.

Olivier-Utard, F. (2003). La dynamique d'un double héritage. Les relations universitaireenterprise à Strasbourg. Actes de la recherché en sciences sociales, (148), 20-33.

Schinn, T. (2002). Nouvelle production du savoir et triple hélice. Tendances du prêt-à-penser les sciences. Actes de la recherché en sciences sociales, (141-142), 21-30.

Sclove, R. E. (2000). Town Meetings on Technology: Consensus Conferences as Democratic Participation. In D. L. Kleinman (Ed.), Science, Technology and Democracy (pp. 33-48). State University of New York Press.

Thackray, A. (1980). History of science. In P. T. Durbin (Ed.), A Guide to the Culture of Science, Technology, and Medicine (pp. 3-69). Free Press.

\section{References}

Barclay, F. (2021). Postcolonial Realms of Memory: Sites and Symbols in Modern France. French Studies, 75(3), 420-421. https://doi.org/10.1093/fs/knab076 [in English].

Genin, Ch. (2006). Les études culturelles: une résistance française? [Cultural studies: French resistance?]. MEI, 24-25 (Études culturelles / Cultural Studies), 43-55 [in French].

Gingras, Y. (1991). L'institutionnalisation de la recherche en milieu universitaire et ses effets [The institutionalisation of research in universities and its effects]. Sociologie et sociétés, 23(1), 41-54 [in French].

Gingras, Y. (2004). Motiv radikalizma. O nekotorykh novykh tendentsiyakh v sotsiologii nauki i tekhnologii [The Motive of Radicalism. On some new trends in the sociology of science and technology. Journal of Sociology and Social Anthropology, 7(5), 75-98 http://bourdieu.name/files/Zhangra\%20lv.\%20Motiv\%20radikalizma\%20(ZhSSA,\%20 2004)(ru)(T)(24s).pdf [in Russian].

Godin, B., \& Gingras, Y. (2000). The place of universities in the system of knowledge production. Research policy, 29(2), 273-278 [in English].

Kozlov, S. L. (2020). Implantatsiya. Ocherki genealogii istoriko-filologicheskogo znaniya vo Frantsii [Implantation. Essays on the genealogy of historical and philological knowledge in France]. Novoe literaturnoe obozrenie [in Russian].

Lisovich, I. I. (2015). Skal'pel' razuma i kryl'ya voobrazheniya: Nauchnye diskursy v angliiskoi kul'ture rannego Novogo vremeni [The Scalpel of Reason and the Wings of the Imagination: Scientific Discourses in Early Modern English Culture]. Izdatel'skij dom Vysshei shkoly ekonomiki [in Russian]. 
Merton, R. (1993). Effekt Matfeya v nauke, II. Nakoplenie vygod i simvolika intellektual'noi sobstvennosti [The Matthew Effect in Science, II: Cumulative Advantage and the Symbolism of Intellectual Property]. THESIS, 3, 256-276 [in Russian]

Merton, R. (2007). Nauka i obshchestvennyi poryadok [Science and social order]. Social Theory Issues, 1(1), 191-207. https://iphras.ru/uplfile/root/biblio/vst/2007/merton.pdf [in Russian].

Olivier-Utard, F. (2003). La dynamique d'un double héritage. Les relations universitaireenterprise à Strasbourg [The dynamics of a double inheritance. University-business relations in Strasbourg]. Actes de la recherché en sciences sociales, (148), 20-33 [in French].

Schinn, T. (2002). Nouvelle production du savoir et triple hélice. Tendances du prêt-à-penser les sciences [New production of knowledge and triple helix. Trends in ready-to-think science]. Actes de la recherché en sciences sociales, (141-142), 21-30 [in French].

Sclove, R. E. (2000). Town Meetings on Technology: Consensus Conferences as Democratic Participation. In D. L. Kleinman (Ed.), Science, Technology and Democracy (pp. 33-48). State University of New York Press [in English].

Shehavtsova, S. (2020). Linhvokulturolohichna kompetentnist maibutnikh fakhivtsiv yak kliuchova u suchasnomu osvitnomu prostori [Linguo-cultural competence of future specialists as a key in the modern educational space]. Bulletin of Luhansk Taras Shevchenko National University. Pedagogical Sciences, 2(333), 2, 72-79 [in Ukrainian].

Thackray, A. (1980). History of science. In P. T. Durbin (Ed.), A Guide to the Culture of Science, Technology, and Medicine (pp. 3-69). Free Press [in English].

Veber, M. (1990). Izbrannye trudy [Selected Works]. Progress [in Russian].

\section{- FRENCH CULTURAL STUDIES: FEATURES AND TRENDS}

\section{- Bohdana Nosenok}

- PhD student, ORCID: 0000-0002-3034-9217, e-mail: danynosenock@gmail.com,

Taras Shevchenko National University of Kyiv,

Kyiv, Ukraine

\section{Abstract}

The purpose of the article is to identify the features of French cultural studies, as well as to reveal the social nature of French culturology. Given the logic of this article, an important task is to demonstrate the development of French cultural research, to outline the features of the development of culturology in the French sociocultural space. The research methodology deals with the study of sources on the history of culturology in France and its place in the science system of this country. The author of the article applies an interdisciplinary approach and the guidelines of the assemblage theory. The scientific novelty of the article consists in determining the features of the development of cultural research in France. In particular, we are talking about 
finding a place for culturology and cultural research. This paper addresses the problematic issue of the specific character and significance of Études culturelles in the system of sciences in France. Conclusions. French cultural studies - Études culturelles - focuses on three key fields: art, writing, language. French culturologists are convinced that the linguistic environment cannot exist separately from society. Therefore, French research in the field of cultural studies balances between two areas: humanities and social science. In particular, the article demonstrates that French culturology is characterised by the following points: understanding of culture as a visible territory where the struggle to protect a certain idea of France continues; the emphasis on the concept of "nation"; the connection between the development of culture and educational reform; the creation of a universal system of national education by the state; attention to the development of language and literature. In France, cultural studies remains controversial, something poorly understood, because French thinkers are classics for these interdisciplinary humanities. The idea of resistance and "denial of culture" often comes to the fore. However, there is a theme that unites French culturologists: the criticism of relativism, which is attributed to culturology in the name of protecting the school.

Keywords: culturology; the humanities; interdisciplinarity; social knowledge; French cultural studies

\section{ФРАНЦУЗСКИЕ КУЛЬТУРАЛЬНЫЕ СТУДИИ: ОСОБЕННОСТИ И ТЕНДЕНЦИИ}

\section{- Носенок Богдана Эдуардовна}

\section{Аспирантка,}

ORCID: 0000-0002-3034-9217, e-mail: danynosenock@gmail.com, Киевский национальный университет имени Тараса Шевченко, Киев, Украина

\section{Аннотация}

Целью статьи является выявление особенностей французских культуральных исследований, а также раскрытие социального характера французской культурологии. Учитывая логику данной статьи, важная задача - продемонстрировать развитие французских культуральных исследований, определить особенности развития культурологии во фрранцузском социокультурном пространстве. Методология статьи связана с обработкой источников, посвященных истории становления культурологии во Франции, а также ее места в системе наук этой страны. В ходе написания исследовательской работы были использованы междисциплинарный подход и установки теории ассамбляжей. Научная новизна статьи заключается в определении особенностей развития исследований культуры во Франции. В частности, речь идет о поисках места культурологии и культурологических исследований. Представленная работа касается проблемного вопроса о специфике и значении Études culturelles в системе наук во Франции. Выводы. Французские культуральные исследования - Études culturelles сосредотачиваются вокруг трех ключевых полей: искусство, письмо, речь. Французские 
ученые-культурологи уверены: лингвистическая среда не может существовать отдельно от социума. Следовательно, французские исследования в области культурологии балансируют между двумя направлениями: humanities и social science. Было, в частности, обнаружено, что для французской культурологии характерны следующие моменты: понимание культуры как видимой территории, на которой продолжается борьба по защите определенной идеи Франции; упор на понятие «нация»; связь развития культуры и реформы образования; создание государством универсальной системы национального образования; внимание к развитию языка и литературы. Во Франции культуральные исследования остаются противоречивыми, они во многом плохо понятны, поскольку французские мыслители являются классикой для этих междисциплинарных гуманитарных наук. На первый план часто выходит идея сопротивления и «отрицания культуры». Однако есть и тема, объединяющая французских культурологов: критика релятивизма, которую приписывают культурологии во имя защиты школы.

Ключевые слова: культурология; гуманитаристика; междисциплинарность; социальное знание; французские культуральные исследования 